\title{
Stowarzyszenie Rodzin Wielokulturowych - organizacja pozarządowa reprezentująca interesy osób odmiennych kulturowo
}

\section{KEYWORDS}

multicultural families, non-governmental organization, association, cultural diversity, Multicultural Families Association

\begin{abstract}
Sowa-Behtane Ewa, Stowarzyszenie Rodzin Wielokulturowych - organizacja pozarządowa reprezentująca interesy osób odmiennych kulturowo [Multicultural Families Association - a non-governmental organization representing the interests of persons with different cultures]. Kultura - Społeczeństwo - Edukacja nr 1(13) 2018, Poznań 2018, pp. 117-126, Adam Mickiewicz University Press. ISSN 2300-0422. DOI 10.14746/kse.2018.13.9.

The article attempts to shows that in the era of post-modernity, the ethnically, racially, religiously, culturally or nationally mixed marriages are more and more frequent phenomenon, contributing to the emergence of new types of cultural identity. The degree of cultural difference determines the number of problems which occur between partners. National, religious, linguistic and cultural differences can affect both positively and negatively functioning multicultural families.

The main context of this article is the activity of Multicultural Families Association, which was formed in the aftermath of diagnosis multicultural families living in Krakow. The Association responds to the needs of these families.
\end{abstract}

\section{Wstęp}

W XXI wieku małżeństwa mieszane etnicznie, rasowo, religijnie, kulturowo czy narodowościowo, często stanowiące zaczątek nowych rodzajów tożsamości kulturowej, nie są charakterystyczne tylko dla typowych społeczeństw wielokulturowych Stanów Zjednoczonych, Wielkiej Brytanii, Niemiec, Holandii czy Francji. 
Również w Polsce małżeństwa mieszane narodowościowo stają się zjawiskiem statystycznie coraz częstszym.

Ze zjawiskiem rodzin wielokulturowych i małżeństw mieszanych kulturowo połączone jest zjawisko amalgamacji, czyli wielokrotnej tożsamości „ponad podziałami” etnicznymi czy narodowymi.

Współcześnie, dzięki Internetowi i coraz łatwiejszej komunikacji między różnymi krajami, mamy do czynienia ze stanem tak zwanego „zmniejszenia się” świata i tym samym zwiększenia się liczby osób pochodzących z różnych krajów, które spotykają się, tworzą związek, a następnie zakładają rodzinę. W związku z tym rodziny wielokulturowe stają się coraz częściej podmiotem badań naukowych.

Małżeństwa zawierane z osobami odmiennymi kulturowo są rodzajem wskaźnika otwartości społeczeństwa na kontakty z innymi kulturami, krajami, pośrednio informując również o skali długotrwałej emigracji lub imigracji, prowadzącej do możliwości wystąpienia trwałej, intymnej więzi pomiędzy obywatelami dwóch państw. Gdy ludzie wywodzący się z różnych narodów łączą się w pary małżeńskie, dochodzi do bardzo ważnych zjawisk i procesów. W wyniku amalgamacji wyłania się nowy ład kulturowy.

\section{Osoby odmienne kulturowo w Polsce}

Wielokulturową Polskę tworzą mniejszości narodowe i etniczne zamieszkujące teren Polski od dawien dawna oraz imigranci, który przybywają do Polski z wielu różnych powodów, tożsamych z powodami imigracji do innych krajów (praca, połączenie z rodziną, studia).

Mniejszością narodową jest grupa obywateli polskich, która jest mniej liczebna od pozostałej części ludności Rzeczypospolitej Polskiej; w sposób istotny odróżnia się od pozostałych obywateli językiem, kulturą lub tradycją; dąży do zachowania swojego języka, kultury lub tradycji; ma świadomość własnej historycznej wspólnoty narodowej i jest ukierunkowana na jej wyrażanie i ochronę; jej przodkowie zamieszkiwali obecne terytorium Rzeczypospolitej Polskiej od co najmniej 100 lat oraz utożsamia się z narodem zorganizowanym we własnym państwie ${ }^{1}$. Polskę zamieszkuje dziewięć mniejszości narodowych: Białorusini, Czesi, Litwini, Niemcy, Ormianie, Rosjanie, Słowacy, Ukraińcy i Żydzi oraz cztery mniejszości etniczne: Karaimi, Łemkowie, Romowie i Tatarzy. Mniejszością etniczną jest grupa obywa-

${ }^{1}$ Ustawa z dnia 6 stycznia 2005 r. o mniejszościach narodowych i etnicznych oraz o języku regionalnym (Dz.U. z 2005 r. Nr 17, poz. 141), s. 1. 
teli polskich, którą od mniejszości narodowych różni jedna cecha: nie utożsamia się z narodem zorganizowanym we własnym państwie. Pozostałe cechy są tożsame z tymi, które definiują mniejszości narodowe².

Podczas przeprowadzonego w 2011 roku narodowego spisu powszechnego ludności i mieszkann ${ }^{3}$ narodowość niemiecką zadeklarowało 144238 obywateli polskich, białoruską - 43 880, ukraińską - 38 797, rosyjską - 8796, litewską - 7374, żydowską - 7353, czeską - 2833, słowacką - 2740, a ormiańską 1684 obywateli polskich. Przynależność do mniejszości romskiej zadeklarowało 16725 obywateli polskich, do łemkowskiej - 9641, do tatarskiej - 1828, a do karaimskiej 313 obywateli polskich.

Ponadto, tereny województwa pomorskiego zamieszkują Kaszubi - grupa etniczna kultywująca tradycje regionalne oraz używająca języka różniącego się od języka polskiego. Liczebność tej grupy szacuje się na około 350-500 tysięcy osób4 Polskie ustawodawstwo nie uznaje Kaszubów za mniejszość etniczną, ale język kaszubski jest uznawany za język regionalny.

Mimo że Polska jest tradycyjnie traktowana jako kraj emigracji, w ostatnich latach zmienia się w kraj imigracyjny, głównie poprzez członkostwo w Unii Europejskiej. Imigranci zaczęli odgrywać ważną rolę na polskim rynku pracy, co stwarza dodatkowe wyzwanie dla struktury instytucjonalnej.

Generalnie można zidentyfikować w Polsce pięć grup imigrantów. Są to obcokrajowcy reprezentujący Europejski Obszar Gospodarczy i Szwajcarię, państwa członkowskie OECD (z wyjątkiem Europejskiego Obszaru Gospodarczego i Szwajcarii), kraje Europy Wschodniej sąsiadujące z Polską (głównie Białoruś, Ukraina i Rosja), kraje Dalekiego Wschodu (głównie Wietnam i Chiny) oraz inne regiony.

Informacje o liczbie imigrantów w Polsce gromadzi organizacja o nazwie Hafelekar. We współpracy z fundacjami „Leonardo da Vinci” i „Job-in-a-job” Hafelekar stworzył Raport na temat imigrantów w Polsce ${ }^{5}$ z którego wynika, że imigranci przybywają do Polski głównie z krajów byłego ZSRR (Ukraina, Białoruś i Rosja). Stosunkowo dużą grupą imigrantów w Polsce są obywatele z krajów rozwiniętych (Stany Zjednoczone, Niemcy, Francja i Wietnam). Co trzeci obcokrajowiec mieszkający w Polsce pochodzi z krajów sąsiednich. Najwięcej imigrantów przybyło do

2 Tamże, s. 2.

3 Raport z wyników. Narodowy spis powszechny ludności i mieszkań z 2011 roku, GUS, Warszawa 2012, http://stat.gov.pl/cps/rde/xbcr/gus/lud_raport_z_wynikow_NSP2011.pdf, dostęp: 20.05.2016.

4 III Raport dla Sekretarza Generalnego Rady Europu z realizacji przez Rzeczpospolita Polska postanowień Konwencji ramowej Rady Europy o ochronie mniejszości narodowych, Warszawa 2002.

5 Hafelekar: Report about immigrants in Poland. http://hafelekar.at/CD_JIJ/pdf/pdf_pol/raport_ projektowy_na_temat_sytaucji_imigrantow_w_polsce.pdf, dostęp 3.06.2016. 
Polski z Ukrainy (26,6\% wszystkich imigrantów). Dość duża liczba osób przybyła z Białorusi $(9,2 \%)$ i Chin (4,2\%). Istnieją dwie główne cechy imigrantów mieszkających w Polsce. Po pierwsze, są oni na ogół bardzo dobrze wykształceni (36\% to absolwenci szkół wyższych), są przede wszystkim osobami w wieku produkcyjnym ( $80 \%$ w wieku od 20 do 59 lat) posiadającymi w Polsce pracę. Oznacza to, że do Polski emigrują ludzie aktywni zawodowo, w większości mężczyźni, a nie całe rodziny imigranckie. Cudzoziemcy z różnych części świata nie osiedlają się w tych samych regionach Polski. Obywatele krajów Europy Zachodniej i Stanów Zjednoczonych mieszkają przede wszystkim w Warszawie i Krakowie lub okolicy. Cudzoziemcy pochodzący z krajów byłego Związku Radzieckiego żyją głównie we wschodnich prowincjach. Największa liczba imigrantów mieszka w województwie mazowieckim (30\%). Dalej w rankingu plasuje się województwo małopolskie, dolnośląskie i łódzkie. Około 83\% imigrantów mieszka w miastach.

Zarówno osoby reprezentujące mniejszości narodowe czy etniczne, jak i imigranci przebywający na terenie Polski to osoby odmienne kulturowo od kultury dominującej, czyli narodowej polskiej. Będą to zatem osoby, dla których polska kultura narodowa:

- nie będzie kulturą własną, ale kulturą obcą;

- jest jedną z wielu kultur własnych (wielokulturowa tożsamość jednostki);

- jest cząstką indywidualnej tożsamości transkulturowej, czyli takiej, na którą składają się elementy różnych kultur, ale nie można jednoznacznie określić, które elementy pochodzą z której kultury, gdyż następuje ich wymieszanie i stworzenie zupełnie nowej jakości kulturowej, której nie można dopasować do żadnej kultury narodowej.

Dlaczego warto prowadzić badania osób odmiennych kulturowo w danym społeczeństwie, nawet jeśli wydaje się ono (jak społeczeństwo polskie) względnie homogeniczne kulturowo? Są dwa zasadnicze powody, na które uwagę zwrócił Janusz Mucha w książce Kultura dominująca jako kultura obca. Po pierwsze, możemy dowiedzieć się czegoś ważnego o tych zbiorowościach, a po drugie, możemy lepiej zrozumieć szerszą grupę, w której te zbiorowości funkcjonują, czyli w naszym przypadku polską zbiorowość dominującą kulturowo (por. Mucha, 1999).

\section{Rodziny wielokulturowe}

Interesującą mnie kategorią osób odmiennych kulturowo są członkowie rodzin wielokulturowych, rozumianych jako rodziny, w których reprezentowane i kultywowane są różne kultury (narodowe, etniczne). Bardzo często są to dwie kultu- 
ry (męża oraz żony), jednak gdy małżeństwo nie zamieszkuje kraju pochodzenia żadnego z partnerów, dochodzi kolejna - ta, w której żyje i funkcjonuje rodzina. Zdarza się też, że jeden z partnerów małżeństwa pochodzi ze środowiska rodzinnego wielokulturowego i już on sam reprezentuje tożsamość wielokulturową bądź transkulturową. Na ile i w jakim zakresie są przyswajane i kultywowane wzory, wartości czy normy kulturowe poszczególnych kultur pozostaje kwestią do zbadania, ale wybiegającą poza ramy niniejszych rozważań.

Wielokulturowość rodziny można zatem rozumieć jako współobecność i współoddziaływanie w obszarze aktywności rodziny różnych wzorów kulturowych, czyli „współistnienie w obrębie grup pierwotnych, gdzie przeważają kontakty osobiste i zbliżenia" (Komorowski, 1975: 260). Leszek Korporowicz zauważa, że coraz częściej stajemy i jeszcze częściej stawać będziemy przed zjawiskiem „(..) wielokulturowości rodzin i wielojęzyczności socjalizacji, przed różnorodnymi przejawami stresu kulturowego, jak również przed poszukiwaniem nowych form tożsamości kulturowej i osobowej jednostek znajdującej się w sytuacji pogranicza, wielości, a często i rozbieżności identyfikacji” (Korporowicz, 1997: 45). To pierwszy z problemów dotykających członków rodzin wielokulturowych, a w szczególności dzieci, które mogą mieć trudności z określeniem siebie, z odpowiedzią na pytanie: kim jestem?

W rodzinach wielokulturowych wyznawane są często różne religie. Wtedy rodzina nie jest tylko wielokulturowa, ale również wieloreligijna. Takie związki międzykulturowe z jednej strony prezentują otwartość na inne wyznania, chęć poznania i tolerancję. Partnerzy mogą rozwinąć się duchowo, poszerzać wiedzę na temat własnej religii, gdyż porównują ją z religią partnera (por. Romano, 2008). Z drugiej jednak strony odmienność religijna rodzi rozbieżność postaw, filozofii życia, a przede wszystkim często prowadzi do trudności w zawarciu kompromisu w sprawie religii wspólnych dzieci. Ilość problemów wzrasta, gdy zachowanie jednego z partnerów nie jest zgodne z zasadami wiary drugiego partnera.

Rodziny wielokulturowe cechują się też w większości przypadków wielojęzycznością. Przez rodzinę wielojęzyczną będziemy rozumieć rodzinę, w której członkowie w życiu codziennym używają dwóch i więcej języków. Wielojęzyczność to zjawisko wielokroć pozytywne, gdyż zapewnia jednostce posługującej się wieloma językami szersze pole komunikacji, pracy, działań etc. Jednak nie należy zapominać o problemach, które mogą wynikać z posługiwania się przez partnerów odmiennymi językami ojczystymi. Często niemożność pełnego zrozumienia toku myślenia partnera, niezwykle ważnego dla prawidłowego funkcjonowania każdego związku, jest wynikiem nieznajomości jego mowy ojczystej. 
Jak wynika z badań prowadzonych wśród małżeństw mieszanych kulturowo,

stopień odmienności kulturowej determinuje ilość problemów występujących między partnerami. Różnice narodowościowe, religijne, językowe i kulturowe mogą wpływać zarówno negatywnie, jak i pozytywnie na partnerstwo lub małżeństwo. Rezultat uwarunkowany jest m.in. stopniem podobieństwa partnera, stopniem bariery językowej, akceptacją odmiennej kultury i religii partnera oraz jego odrębnych poglądów. (Sowa-Behtane, 2015: 27)

Do czynników generujących problemy w związkach mieszanych zaliczyć można: różnice kultur narodowych, założenie podobieństwa interlokutorów, różnice językowe, niepoprawną interpretację sygnałów niewerbalnych, stereotypy i uprzedzenia, odmienny system wartości, lęki i napięcia, niepewność i stres, etnocentryzm, szok kulturowy, odmienność religijną, a nawet kulturowe modele zaspokajania głodu. Prócz problemów mogących występować w samych rodzinach dochodzą problemy zewnętrzne, takie jak: brak akceptacji ze strony rodziny/rodzin, czy szerszego kręgu społecznego, brak tolerancji wobec członków takich rodzin, trudności ze znalezieniem pracy, brak akceptacji dzieci z rodzin wielokulturowych w szkołach. Osobną kategorię problemów stanowią te dotyczące integracji przedstawiciela odmiennej kultury ze społeczeństwem przyjmującym.

Wyróżniać będziemy dwa zasadnicze rodzaje rodzin wielokulturowych: te, w których jeden z członków jest przedstawicielem narodowości i kultury polskiej, oraz rodziny cudzoziemskie bądź reprezentujące mniejszości narodowe i etniczne, przyjmujące kulturę polską jako drugą. Zarówno jeden, jak i drugi typ może spotykać się z pewnymi rodzajami problemów. Celowe zatem wydaje się, by rodziny wielokulturowe otrzymywały wsparcie i pomoc w różnorodnej postaci.

\section{Instyłucje współpracujące z osobami odmiennymi kulturowo}

Klasyfikacji instytucji współpracujących z osobami odmiennymi kulturowo można dokonać ze względu na statut prawny tychże osób bądź grup. Wyróżnić zatem możemy instytucje skierowane do mniejszości narodowych i etnicznych, do repatriantów i cudzoziemców, którym udzielono ochrony międzynarodowej oraz do imigrantów nienależących do żadnej z dwóch poprzednich grup.

Funkcjonowanie mniejszości narodowych i etnicznych wspierają: Wydział Mniejszości Narodowych i Etnicznych powołany w strukturze Ministerstwa Spraw Wewnętrznych i Administracji oraz pełnomocnicy wojewodów ds. mniejszości narodowych i etnicznych. 
Po wejściu Polski do Unii Europejskiej rząd dostosował swoją politykę migracji do standardów w niej obowiązujących. Zgodnie z dokumentem Polityka migracyjna Polski - stan aktualny, a dalsze działania, który został opracowany przez międzyresortowy Komitet do spraw Migracji w lipcu 2011 roku, polskie instytucje państwowe są zobowiązane do zapewnienia szczególnego wsparcia i usług dla repatriantów i cudzoziemców, którym udzielono ochrony międzynarodowej. Ale wobec innych kategorii obywateli (np. z państw trzecich) instytucje państwowe nie są zobowiązane do ich wspierania. To zadanie jest pozostawione dla organizacji pozarządowych, które opierają swoje działania na zewnętrznych źródłach finansowania.

W Polsce istnieje wiele organizacji non-profit, których misją jest rozwijanie otwartego, zróżnicowanego społeczeństwa poprzez wspieranie dialogu międzykulturowego i integrację społeczną, walkę $\mathrm{z}$ dyskryminacją, poszerzanie wiedzy i rozwijanie narzędzi, które wzmacniają integrację społeczną i równość imigrantów. Prace polskich NGO zmierzają do kształtowania społeczeństwa, w którym każdy człowiek czuje się wolny i bezpieczny, może rozwijać się i uczestniczyć w życiu społecznym zgodnie z jego potrzebami i ambicjami niezależnie kim jest i skąd pochodzi, i w którym różnorodność społeczna jest szanowana, ceniona i pielęgnowana. Jedną $\mathrm{z}$ takich organizacji pozarządowych jest Stowarzyszenie Rodzin Wielokulturowych.

\section{Stowarzyszenie Rodzin Wielokulturowych ${ }^{6}$}

Stowarzyszenie Rodzin Wielokulturowych zostało zarejestrowane w KRS 24 kwietnia 2015 roku. Pomysł założenia stowarzyszenia zrodził się z diagnozy potrzeb rodzin wielokulturowych wykonanej w latach 2013-2015 na terenie Krakowa. Obszary działań stowarzyszenia to: edukacja, poradnictwo, terapia, integracja i aktywność cudzoziemców, zajęcia kulturalne, oświatowe i rekreacyjne, promocja wielokulturowości oraz nauka.

Stowarzyszenie prowadzi działania na rzecz społeczeństwa wielokulturowego ze szczególnym uwzględnieniem członków rodzin wielokulturowych. Jego zadaniem jest inicjowanie, promocja i popieranie działań mających na celu kompleksową pomoc cudzoziemcom znajdującym się na terytorium Rzeczypospolitej Polskiej, jak również ochrona członków rodzin wielokulturowych przed

${ }^{6}$ Strona internetowa Stowarzyszenia Rodzin Wielokulturowych: http://rodzinawielokulturowa. pl, dostęp: 14.10.2016. 
wykluczeniem społecznym. Kolejnym zadaniem, którego się podejmuje, jest pomoc uchodźcom, osobom $\mathrm{z}$ ochroną uzupełniającą lub pobytem tolerowanym, imigrantom oraz osobom ubiegającym się o status uchodźcy lub inną formę legalizacji pobytu w Polsce. Stowarzyszenie prowadzi działania na rzecz integracji osób innych narodowości z przyjmującym społeczeństwem polskim, jak również działania zapobiegające dyskryminacji z racji przynależności do odmiennej narodowości, kultury i religii.

Kolejnym zadaniem realizowanym przez Stowarzyszenie jest wszechstronne propagowanie informacji, metod i technik w zakresie działalności antyrasistowskiej i antydyskryminacyjnej oraz pobudzanie świadomości społeczeństwa polskiego w zakresie rosnącej liczby cudzoziemców w Polsce. Prowadzi ono działalność na rzecz mniejszości narodowych i etnicznych. Innym zadaniem jest upowszechnianie wiedzy o tematyce wielokulturowej, odmiennych kulturach i religii cudzoziemców znajdujących się na terenie RP oraz o stosunkach Polski z innymi państwami. Nie mniej ważnym zadaniem jest propagowanie porozumienia międzykulturowego oraz promocja i wspieranie dialogu międzykulturowego, $w$ tym pogłębianie wiedzy o krajach pochodzenia uchodźców, imigrantów oraz o mniejszościach etnicznych i narodowych.

Celem Stowarzyszenia jest budowanie „pomostu porozumienia” pomiędzy przedstawicielami społeczności o odmiennych tradycjach kulturowych, religijnych i światopoglądowych między innymi poprzez koordynowanie przedsięwzięć służących lepszemu poznaniu się społeczeństwa polskiego i żyjących w Polsce cudzoziemców. Prowadzi ono również działalność wspomagającą rozwój wspólnot i społeczności lokalnych oraz działalność na rzecz integracji i reintegracji zawodowej i społecznej osób z rodzin wielokulturowych. Kolejnym zadaniem Stowarzyszenia jest podtrzymywanie i upowszechnianie tradycji narodowej oraz języka różnych kultur, z których pochodzą członkowie rodzin mieszanych oraz działalność na rzecz równych praw kobiet i mężczyzn w związkach wielokulturowych.

Wyżej wymienione zadania realizowane są w następujących formach:

a) warsztaty, szkolenia, konferencje, seminaria, wykłady, prelekcje, kursy, zajęcia dydaktyczne;

b) imprezy kulturalne, wystawy, wernisaże;

c) diagnoza (psychologiczno-pedagogiczna), poradnictwo (pedagogiczne, socjalne, prawne, zawodowe, psychologiczne), mediacja i terapia;

d) współpraca z instytucjami publicznymi, ośrodkami kultury, Kościołami i związkami wyznaniowymi, organizacjami, stowarzyszeniami i grupami etnicznymi, narodowościowymi i kulturalnymi w Polsce i za granicą; 
e) rozwijanie współpracy międzynarodowej, w szczególności poprzez wymianę doświadczeń, realizację wspólnych programów, konferencje, seminaria i innego rodzaju działania;

f) nawiązywanie współpracy z mediami i innymi niezależnymi organizacjami czy instytucjami na przykład edukacji i oświaty;

g) monitorowanie prowadzonych działań;

h) wiece, zgromadzenia i happeningi;

i) badania naukowe, działalność wydawnicza, publicystyczna;

j) występowanie z wnioskami i zapytaniami do odpowiednich organów państwowych i międzynarodowych.

Stowarzyszenie Rodzin Wielokulturowych jest pierwszą w Polsce organizacją pozarządową, która prowadzi działalność ukierunkowaną na pomoc rodzinom wielokulturowym.

\section{Zakończenie}

Rodzina wielokulturowa, jak każda inna, musi radzić sobie z wieloma zagrożeniami i problemami. Bywa tak, że swoje problemy jest w stanie rozwiązać, wykorzystując własne zasoby, jeśli jednak strategie rozwiązywania problemów wewnątrzrodzinnych przy udziale jej członków zawodzą, zachodzi konieczność udzielania pomocy z zewnątrz. Oferuje ją Stowarzyszenie Rodzin Wielokulturowych. Pomoc powinna być zintegrowana, czyli powinna występować spójność oddziaływań: od diagnozy do środków zaradczych. Dla trafności podejmowanych działań niezbędna jest diagnoza uwzględniająca całość funkcjonowania rodziny, podczas której należy zwrócić uwagę na elementy takie jak: zaplecze kulturowe osób badanych, zaplecze językowe oraz sytuacja zmiany kulturowej. Stowarzyszenie kieruje do nich poradnictwo specjalistyczne, w szczególności prawne, psychologiczne i rodzinne, mediację oraz terapię rodzinną. Jednakże funkcjonowanie rodzin wielokulturowych uzależnione jest również od społeczeństwa, którego są one członkami.

Zatem niezmiernie ważna jest prowadzona przez Stowarzyszenie edukacja wielokulturowa skierowana do całego społeczeństwa, która ma służyć przygotowaniu dzieci i młodzieży, niezależnie od pochodzenia i kultury, do życia i współdziałania na zasadach równorzędnego spotkania kultur, a nie na zasadzie dominacji mniejszości nad większością czy odwrotnie. Bez wątpienia Stowarzyszenie stara się reprezentować interesy osób odmiennych kulturowo. 